\title{
Correlation between Health Perception, Body Image, and Eating Habits in High School Students
}

\author{
Abdullah Ichsan, ${ }^{1}$ Irvan Afriandi, ${ }^{2}$ Dida Akhmad Gurnida ${ }^{3}$ \\ ${ }^{1}$ Faculty of Medicine Universitas Padjadjaran, ${ }^{2}$ Department of Public Health Faculty of \\ Medicine Universitas Padjadjaran, ${ }^{3}$ Department of Child Health Faculty of Medicine Universitas \\ Padjadjaran/Dr. Hasan Sadikin General Hospital Bandung
}

\begin{abstract}
Background: Mental disorders, including eating disorders, mostly begin during youth. Moreover, negative body image is found to cause unhealthy eating habits in the context of several cross-cultural settings. This study aimed to examine the correlation between health perception and body image with eating habits among high school students.

Methods: A structured, anonymous questionnaire was distributed to students of a private high school in Bandung, Indonesia in June-October 2014. The questionnaire included questions about health perception, body image, eating habits, body weight and height, and also other demographic parameters. The school was selected as the study object through purposive sampling, and 140 high school students (72 male and 68 female) were ramdomly selected.

Results: Male and female did not show considerable differences in health perceptions. Out of 13 statements, 12 statements of male respondents showed better body image than female. While in eating habits statements, female respondents seemed to maintain healthier eating habits than male respondents. No significant correlation was observed between body image and eating habits $(r=-0.015, p=0.858)$. There was significant correlation between health perception and eating habits $(r=0.374, p<0.001)$. Correlation between sex and eating habits was found $(\mathrm{p}=0.020)$, there was not significant relationship between eating habits and Body Mass Index (BMI) ( $\mathrm{p}=0.368)$.

Conclusions: The negative relationship between body image and eating habits is not significant. However there was a significant positive relationship between health perception and eating habits. Furthermore, there was correlation between sex and eating habits, while the positive relationship between eating habits and BMI was still not found. [AMJ.2016;3(2):216-21]
\end{abstract}

Keywords: Body image, body mass index, health perception, high school students, nutritional habits

\section{Introduction}

While infections are continuously being eradicated in developed countries, the numbers of non-communicable diseases patients are arising as well. Moreover, it is currently very common to hear about "double burden diseases" in developing countries. It means that those countries are not only facing communicable diseases, but also noncommunicable diseases. Unfortunately, only a few people realize that those dangerous non-communicable diseases, such as cardiometabolic diseases, hypertension, cancers, can also be prevented by having proper nutrition. ${ }^{1}$

Medical practitioners should realize that mental disorders mostly begin during youth, which is $12-24$ years of age, although they are often diagnosed or detected later in life. ${ }^{2}$ Moreover, a study involving British and Malaysian women shows that BMI is the primary determinant of female physical attractiveness. $^{3}$

The aim of this study was to examine the correlation between health perception and body image with eating habits among high school students. This study expected to obtain more appropriate intervention for reducing the risk of having eating disorder and improving positive health behaviors which can be well-planned. Thus, it could be hypothesized that negative relationship would be observed between body image and eating

Correspondence: Abdullah Ichsan, Faculty of Medicine, Universitas Padjadjaran, Jalan Raya Bandung-Sumedang Km.21, Jatinangor, Sumedang, Indonesia, Phone: +6289617613761 Email: ichsanlernt@gmail.com 
habits; there would be positive relationship between health perception and eating habits; there would be correlation between sex and eating habits; and positive relationship would be observed between eating habits and Body Mass Index (BMI).

\section{Methods}

A structured, anonymous, self-administrated questionnaire was distributed to students of a private high schools in Bandung, Indonesia in June-October 2014. Some questions were obtained from Jessor's Survey of Personal and Social Development, then it was translated and culturally adapted to suit local students population. ${ }^{4}$ The rest of the questions were developed prior to this study.

The questionnaire included questions about health perception, body image, eating habits, body weight and height, and also other demographic parameters. For the participants' comfort, the questionnaire was simplified and arranged into tables, and separated questions for each variable.

The lists of students' name from each class were obtained from the school's administration sub-division, and then the classes where the questionnaire would be distributed were randomly selected. As many as 140 high school students ( 72 male and 68 female) became the respondents. As they were on the eleventh grade of senior high school, their ages ranged from 15-17 years. Considering that the age of the respondents was still not sufficient to allow them to sign the informed consent letter by themselves; the teacher agreed to sign it for them as teachers are the students' parents at school time.

The health perception of respondents was measured by giving them nine statements, and letting them choose from "never" (scored 0 for positive statements and 3 for negative statements) until "always" (scored 3 for positive statements and 0 for negative statements). Seven from the total nine statements were positive, and the rest two statements on health perceptions were negative. An index was then created for health perceptions (9 items, Cronbach Alpha $=.78$ ).

To measure the respondents' body image, there were thirteen negative statements, and the respondents could choose from "never" (scored 3) until "always" (scored 0). An index was also created for body image (13 items, Cronbach Alpha $=.90$ ).

Furthermore, the respondents eating habits were measured by administering eight statements. Just like the health perceptions questionnaire, they could choose from "never" (scored 0 for positive statements and 3 for negative statements) until "always" (scored 3 for positive statements and 0 for negative statements). Out of the eight statements, six were positive, and the rest two statements were negative. Eating Habits index was also created afterwards (8 items, Cronbach Alpha=.77).

The respondents were recommended to use the healthcare facilities measurement tools in order to measure their body height and weight.

After the ethical clearance was obtained from the Health Research Ethics committee of Faculty of Medicine, Universitas Padjadjaran then, the questionnaires were distributed at learning time in the class for about ten until fifteen minutes. The purpose of the questionnaire distribution performed at learning was to prevent students from leaving the class or finishing the questionnaires in a rush. This was carried out by teachers after the teachers were given explanations how to distribute and fill in the questionnaire.

From a total number of eight classes of grade eleven in the selected high school, the questionnaires were finally distributed to six randomly selected classes. Every student who participated in this study would receive a brief result of this study, and a bookmark with some healthy diet information on it, and the school would receive a copy of the journal and the whole report of this study.

The analysis in this study included descriptive data analysis, relationship tests for the first and second hypothesis using Pearson correlation, simple linear regression for the third hypothesis, and simple logistic regression for the fourth hypothesis. All of those processes were conducted by using computer.

\section{Results}

Male and female did not show considerable differences in health perceptions (Table 1). However, in body image and eating habits the differences between male and female were clearly shown (Table 2 and 3 ). Out of 13 statements, 12 statements of male respondents showed better body image than female. While in eating habits statements, female respondents seemed to maintain healthier eating habits than male respondents.

The first hypothesis claimed that negative relationship could be observed between body 
Table 1 Distribution of Health Perceptions by Gender

\begin{tabular}{clccc}
\hline \multirow{2}{*}{ No } & \multicolumn{1}{c}{ Measurements } & \multicolumn{2}{c}{ Gender } & \multirow{2}{*}{ Total (\%) } \\
\cline { 3 - 3 } & & $\begin{array}{c}\text { Male (\%) } \\
\text { n=72 }\end{array}$ & $\begin{array}{c}\text { Female (\%) } \\
\text { n=68 }\end{array}$ & \\
\hline 1 & $\begin{array}{l}\text { Always consider whether my body is in a healthy } \\
\text { condition }\end{array}$ & $17(23.6)$ & $4(5.9)$ & $21(15)$ \\
2 & $\begin{array}{l}\text { Always consider whether my body has enough } \\
\text { energy to do daily activities }\end{array}$ & $13(18.1)$ & $9(13.2)$ & $22(15.7)$ \\
3 & $\begin{array}{l}\text { Always consider whether my environments are } \\
\text { away from diseases }\end{array}$ & $5(6.9)$ & $6(8.8)$ & $11(7.9)$ \\
4 & $\begin{array}{l}\text { Always agree to do extra efforts or spend extra } \\
\text { money to keep my body in healthy condition }\end{array}$ & $10(13.9)$ & $11(16.2)$ & $21(15)$ \\
5 & $\begin{array}{l}\text { Always consider my health condition compared } \\
\text { with others }\end{array}$ & $15(20.8)$ & $10(14.7)$ & $25(17.9)$ \\
6 & $\begin{array}{l}\text { Always keep healthy eating habits, not too much, } \\
\text { not too little }\end{array}$ & $8(11.1)$ & $9(13.2)$ & $17(12.1)$ \\
7 & $\begin{array}{l}\text { Always clean myself and clean-up my } \\
\text { surroundings }\end{array}$ & $14(19.4)$ & $12(17.6)$ & $26(18.6)$ \\
8 & $\begin{array}{l}\text { Never do things I like if it endanger my health } \\
\text { and safety }\end{array}$ & $3(4.2)$ & $5(7.4)$ & $8(5.7)$ \\
9 & $\begin{array}{l}\text { Never ignore usual symptoms of disease i.e. } \\
\text { runny nose, cough, headache if it occurred } \\
\text { already for several days }\end{array}$ & $16(22.2)$ & $16(23.5)$ & $32(22.9)$ \\
\hline
\end{tabular}

image and eating habits. Unfortunately, the result of Pearson's correlation test showed that the relationship was not significant $(\mathrm{r}=-$ 0.015 , with $\mathrm{p}=0.858$ ) (Table 4).

The second hypothesis then suggested that a positive relationship would be observed between health perception and eating habits. The result was as expected. The result of a Pearson's correlation test had shown a quite strong and significant relationship ( $\mathrm{r}=0.374$, with $\mathrm{p}<0.001$ ) (Table 4).

The third hypothesis indicated that there could be some correlations between sex and eating habits. By using the simple linear regression test, and looking at the distributions, the correlation could be observed $(p=0.020)$ (Table 3).

The fourth, and also the last hypothesis claimed that positive relationship would be observed between eating habits and BMI. Unfortunately, after using the logistic regression test there was no significant relationship found for those variables $(\mathrm{p}=0.368)$.

\section{Discussion}

This study had provided several data which were not easily found, especially in Indonesia.
The data were health perception, body image, eating habits, and the associations between them. However, even the results showed little significant correlations between variables in this study, there were still some phenomena which should still be discussed.

In the first hypothesis, it was claimed that negative relationships between body image and eating habits would be observed. This hypothesis was based on some previous studies, such as a research in Poland ${ }^{5}$ which showed $63.9 \%$ of woman were dissatisfied with their figures, and $33.5 \%$ of them underwent slimming diets at least once. The Tripartite Model of body image and eating disorders (peer, parents, and media) had also been proven to be a useful framework for understanding processes that may predispose young women to develop negative body image and eating disorders. ${ }^{6}$ Unfortunately, in this study, no strong relationship was revealed, whereas female respondents who had relatively negative body image maintained healthier eating habits than male respondents. This study even showed that among high school students, who were also a group of adolescents, there were no significant correlations between body image and eating habits. 
Table 2 Distribution of Body Image by Gender

\begin{tabular}{|c|c|c|c|c|}
\hline \multirow[b]{2}{*}{ No } & \multirow[b]{2}{*}{ Measurements } & \multicolumn{2}{|c|}{ Gender } & \multirow{2}{*}{$\begin{array}{c}\text { Total (\%) } \\
\mathrm{N}=140\end{array}$} \\
\hline & & $\begin{array}{l}\text { Male (\%) } \\
n=72\end{array}$ & $\begin{array}{c}\text { Female }(\%) \\
n=68\end{array}$ & \\
\hline 1 & $\begin{array}{l}\text { Never feel ashamed with my body when facing } \\
\text { someone special. }\end{array}$ & $26(36.1)$ & $9(13.2)$ & $35(25)$ \\
\hline 2 & Never feel that others think bad about my body & $24(33.3)$ & $11(16.2)$ & $35(25)$ \\
\hline 3 & $\begin{array}{l}\text { People never think about my weight the first } \\
\text { time they meet me }\end{array}$ & $50(69.4)$ & $34(50)$ & $84(60)$ \\
\hline 4 & $\begin{array}{l}\text { Never feel that my friends and family feel } \\
\text { ashamed when they are with me }\end{array}$ & $60(83.3)$ & $52(76.5)$ & $112(80)$ \\
\hline 5 & Like my body & $41(56.9)$ & $16(23.5)$ & $57(40.7)$ \\
\hline 6 & $\begin{array}{l}\text { Never quit sports or other outdoor activities } \\
\text { because of feeling ashamed with my appearance }\end{array}$ & $62(86.1)$ & $52(76.5)$ & $114(81.4)$ \\
\hline 7 & Like to see my body on mirrors & $33(45.8)$ & $31(45.6)$ & $64(45.7)$ \\
\hline 8 & $\begin{array}{l}\text { Being the center of attention in a crowd is never } \\
\text { a problem for me. }\end{array}$ & $9(13.2)$ & $17(23.6)$ & $26(18.6)$ \\
\hline 9 & $\begin{array}{l}\text { Never stop enjoying my activities because of } \\
\text { unattractive appearance. }\end{array}$ & $51(70.8)$ & $33(48.5)$ & $84(60)$ \\
\hline 10 & $\begin{array}{l}\text { Never think that shopping some outfits is a bad } \\
\text { idea because I need to consider about my weight }\end{array}$ & $60(83.3)$ & $54(79.4)$ & $114(81.4)$ \\
\hline 11 & Never feel bad of my body weight & $53(73.6)$ & $32(47.1)$ & $85(60.7)$ \\
\hline 12 & Never feel bad even when I'm being fat & $44(61.1)$ & $19(27.9)$ & $63(45)$ \\
\hline 13 & Never looking down or bad about my body & $53(73.6)$ & $31(45.6)$ & $84(60)$ \\
\hline
\end{tabular}

The different result between this study and the other ones might be due to several reasons. First, there were only relatively few studies that had focused on eating habits in adolescents or all age group in overall. Second, this study was only focused on one private high school, in order to eliminate socio-economic confounding the number of samples of this study was somehow insufficient to represent all adolescents in Bandung, moreover in whole Indonesia. It seems that a further study should include a lot more samples in order to obtain more relevant and valid results. For example, a study conducted in Israel $^{7}$ which showed correlations between body image and eating habits included more than one thousand college students from several different faculties.

The second hypothesis suggested that there would be a positive relationship between health perception and eating habits. As shown in the results, this hypothesis was accepted. Another study in Israel $^{7}$ conducted with a similar objective also revealed the same results; there were positive relationships. Although in detail, the study in Israel showed a stronger correlation. This might be due to some reasons of the previous hypothesis in this study where there were only 140 samples, while in the study conducted in Israel, there were more than 1,000 samples. However in overall, the result still revealed the same: a positive correlation between health perception and eating habits could be observed. Besides, it is also in line with the literature which mentioned nutrition knowledge can help individuals choose what foods to eat. ${ }^{8}$

The third hypothesis then indicated there would be a correlation between sex and eating habits which was accepted. The numbers of female, male and the total sample which had good eating habits compared to all samples in this study were listed (Table 3). It seemed that females had better eating habits compared to males. Just like in another study which showed females tend to keep a more balanced diet. ${ }^{9}$

The last hypothesis claimed that a positive relationship would be observed between eating habits and BMI. Surprisingly, in this study, the relationship was not significant. However, this phenomenon can be well explained, as another study had revealed that sex, genetics 
Table 3 Distribution of Eating Habits by Gender

\begin{tabular}{|c|c|c|c|c|}
\hline \multirow[b]{2}{*}{ No } & \multirow[b]{2}{*}{ Measurements } & \multicolumn{2}{|c|}{ Gender } & \multirow{2}{*}{$\begin{array}{c}\text { Total (\%) } \\
\mathrm{N}=\mathbf{1 4 0}\end{array}$} \\
\hline & & $\begin{array}{c}\text { Male (\%) } \\
\mathrm{n}=72\end{array}$ & $\begin{array}{c}\text { Female (\%) } \\
n=68\end{array}$ & \\
\hline 1 & Always reduce fatty foods & $3(4.2)$ & $4(5.9)$ & $7(5)$ \\
\hline 2 & Always eat fresh vegetables & $7(9.7)$ & $14(20.6)$ & $21(15)$ \\
\hline 3 & $\begin{array}{l}\text { Always choose fruits for snacks rather than } \\
\text { sweets, chocolates, or other snacks }\end{array}$ & $7(9.7)$ & $11(16.2)$ & 18 (12.9) \\
\hline 4 & $\begin{array}{l}\text { Always choose baked or boiled foods rather than } \\
\text { fried ones }\end{array}$ & $5(6.9)$ & $6(8.8)$ & $11(7.9)$ \\
\hline 5 & $\begin{array}{l}\text { Always consume fish, nuts, eggs, rather than } \\
\text { meat for protein sources }\end{array}$ & $7(9.7)$ & $13(19.1)$ & $20(14.3)$ \\
\hline 6 & Always reduce sweet foods and beverages & $2(2.8)$ & $3(4.4)$ & $5(3.6)$ \\
\hline 7 & Never consume fast foods when eating outdoors & $3(4.2)$ & $1(1.5)$ & $4(2.9)$ \\
\hline 8 & $\begin{array}{l}\text { Never think that being full is the only goal of } \\
\text { eating foods }\end{array}$ & $9(12.5)$ & $12(17.6)$ & $21(15)$. \\
\hline
\end{tabular}

or family history, physical activity and many other factors had also affected BMI. ${ }^{10}$

Obviously, there is a strong need for the community to gethealth promotion in academic settings. In Indonesia, mental diseases such as anorexia nervosa, bulimia nervosa, and other eating disorders are still being neglected. Most people, especially in Indonesia are not aware about mental health and it makes this problem become worse. Community health professionals should also realize that health education programs help to support healthy choices among students. One study showed that interventions have the potential to reduce sick people, healthcare costs, and also to increase moral and efficiency. ${ }^{11}$

This study provided useful information to plan health education about eating behavior for high school students, which should also be focused on improving their health perception, besides giving education about healthy diets so that the intervention can be effective. Thus by using that method, the intervention targets do not only know what to do, but also why they have to do it.
Lastly, this study has also three main limitations. First, as this study was based on cross-sectional data, it could not determine causal-effect relationships. This study could only determine whether the correlations between variables existed, and if it was possible, determine the strength of the relationship. However, a number of descriptive data and analysis results found in this study were interesting, and hopefully the data could contribute to the existing scientific knowledge regarding the lack of studies focusing on health perception, body image, and eating habits. The second limitation was that the sample of this study was only taken from one local private high school. Even the purpose of this sample selection was to eliminate socioeconomic confounding. Unfortunately, it made the data less representative for the real population which was high school students. The third limitation arose because the variables measured in this study were mostly the personal perception of the respondents; the questionnaire used in this study was selfreported.

Table 4 Correlation between Variables Studied

\begin{tabular}{clccc}
\hline No & & 1 & 2 & 3 \\
\hline 1 & Positive Health Perception & - & \\
2 & Positive Body Image & $.211^{*}$ & - \\
& & $(\mathrm{p}<0.05)$ & & - \\
3 & Healthy Eating Habits & $.374^{*}$ & -.015 & - \\
\hline
\end{tabular}


As conclusion, the negative relationship between body image and eating habits is not significant. However there was a significant positive relationship between health perception and eating habits. Furthermore, it was found that there was correlation between sex and eating habits, while the positive relationship between eating habits and BMI was still not found.

This study then suggested community health professionals to give more attention and education to induce positive health perception, positive body image, and healthy lifestyle including eating behavior. In addition, health education programs should also target parents and school teachers beside the adolescents themselves, since parents and teachers have a very strong effect on supervising their children or students' behaviors.

\section{References}

1. Mokdad AH, Marks JS, Stroup DF, Gerberding JL. Actual causes of death in the United States, 2000. JAMA. 2004;291(10):1238-45.

2. Patel V, Flisher AJ, Hetrick S, McGorry P. Mental health of young people: a global public-health challenge. Lancet. 2007;369(9569):1302-13.

3. Swami V, Tovée MJ. Female physical attractiveness in Britain and Malaysia: a cross-cultural study. Body Image. 2005;2(2):115-28.

4. Jessor R, Turbin MS, Costa MF. Survey of personal and social development at CU.
Institute of Behavioral Sciences, University of Colorado. 2003; Spring:1-36

5. Przybyłowicz KE, Jesiołowska D, ObaraGołębiowska M, Antoniak L. A subjective dissatisfaction with body weight in young women: do eating behaviours play a role? Rocz Państw Zakl Hig. 2014;65(3):243-9.

6. Keery H, Van den Berg P, Thompson JK. An evaluation of the tripartite influence model of body dissatisfaction and eating disturbance with adolescent girls. Body Image. 2004;1(3):237-51.

7. Korn L, Gonen E, Shaked Y, Golan M. Health perceptions, self and body image, physical activity and nutrition among undergraduate students in Israel. PloS one. 2013;8(3):e58543.

8. Kicklighter JR, Koonce VJ, Rosenbloom CA, Commander NE. College freshmen perceptions of effective and ineffective aspects of nutrition education. J Am Coll Health. 2010;59(2):98-104.

9. Stock C, Wille L, Krämer A. Gender-specific health behaviors of German university students predict the interest in campus health promotion. Health Promot Int. 2001;16(2):145-54.

10. Sattar A, Baig S, Naveed ur Rehman, Bashir B. Factors affecting BMI; assessment of the effect of sociodemographic factors on BMI in the population of Ghulam Mohammad Abad Faisalabad. Professional Med J. 2013;20(6):956-64.

11. Lee RL, Loke AJ. Health-promoting behaviors and psychosocial well-being of university students in Hong Kong. Public Health Nurs. 2005;22(3):209-20. 